NBER WORKING PAPER SERIES

\title{
WHAT GOES ON UNDER THE HOOD? HOW ENGINEERS INNOVATE IN THE AUTOMOTIVE SUPPLY CHAIN
}

\author{
Susan Helper \\ Jennifer Kuan \\ Working Paper 22552 \\ http://www.nber.org/papers/w22552 \\ NATIONAL BUREAU OF ECONOMIC RESEARCH \\ 1050 Massachusetts Avenue \\ Cambridge, MA 02138 \\ August 2016
}

The authors gratefully acknowledge the financial support of the US Department of Labor under grant RES115881. The views expressed herein are those of the authors and do not necessarily reflect the views of the National Bureau of Economic Research.

NBER working papers are circulated for discussion and comment purposes. They have not been peer-reviewed or been subject to the review by the NBER Board of Directors that accompanies official NBER publications.

(C) 2016 by Susan Helper and Jennifer Kuan. All rights reserved. Short sections of text, not to exceed two paragraphs, may be quoted without explicit permission provided that full credit, including $(\odot$ notice, is given to the source. 
What Goes on Under the Hood? How Engineers Innovate in the Automotive Supply Chain Susan Helper and Jennifer Kuan

NBER Working Paper No. 22552

August 2016

JEL No. D2,L23,L62

\begin{abstract}
The questions addressed in this volume are motivated by the recognition that engineers play an important role in generating innovation and economic growth. In this chapter, we seek to offer some description of engineering work by looking in detail at a specific manufacturing industryfirms that supply automakers - to gain insight into how engineers create innovation. Autos account for 5\% of US GDP and in 2011, $70 \%$ of auto suppliers contributed design effort, a task typically performed by engineers, making the auto supply chain an important context in which to study engineering and innovation.

Some highlights from our original survey data include a wide range in terms of size and strategies of supply chain companies; a majority was small- to medium-sized, often family-owned. We observed barriers to patenting for manufacturing firms developing process rather than product innovations. And interviews revealed the importance of customers for the innovative efforts of supplier firms. Certain Japanese customers were preferred because they shared expertise and helped suppliers improve, while other, American, customers were viewed as having unreasonable demands for regular, incremental price reductions and did not offer technical or organizational support.
\end{abstract}

\author{
Susan Helper \\ Weatherhead School of Management \\ Case Western Reserve University \\ 11119 Bellflower Rd \\ Cleveland, $\mathrm{OH}$ 44106-7235 \\ and NBER \\ susan.helper@case.edu \\ Jennifer Kuan \\ Tulane University \\ A. B. Freeman School of Business \\ Goldring/Woldenberg Hall \\ 7 McAlister Dr. \\ New Orleans, LA 70115-5698 \\ jkuan1@tulane.edu
}




\section{What Goes on Under the Hood? \\ How Engineers Innovate in the Automotive Supply Chain}

\section{Introduction}

The questions addressed in this volume are motivated by the recognition that engineers play an important role in generating innovation and economic growth. In this chapter, we seek to offer some description of engineering work by looking in detail at a specific manufacturing industry - firms that supply automakers - to gain insight into how engineers create innovation. Autos account for 5\% of GDP (U.S. Dept. of Commerce 2011), and have undergone significant innovation and improvement; over the period 1980 to 2004 , average horsepower nearly doubled. ${ }^{1}$ At the same time, the locus of engineering work has changed significantly. For example, in 2011, 70\% of auto suppliers contributed effort design effort (a task typically performed by engineers), compared with $48 \%$ in $1989 .^{2}$ All of this makes the auto supply chain an important context in which to study engineering and innovation.

Our study also revisits themes from an earlier literature on incremental innovation that focused on manufacturing. Rosenberg (1963) describes 19th century equipment makers, who began inside manufacturing firms, but eventually spun out and helped spread technological change. Clark, Chew and Fujimoto (1987) survey automakers about product development projects, and find differences in the way firms from the US, Japan, and Germany utilize suppliers when introducing new car models. Levin et al. (1987) take care to distinguish process innovation from product innovation in their survey of large industrial firms, and uncover different strategies for appropriating returns to innovation. All of this incremental improvement in processes and in product quality accumulates to produce economically significant change. Rosenberg and Steinmueller (2010) examine engineering practices in aircraft and chemicals industries and point out that Douglas Aircraft's DC-3, which served 95\% of US air traffic, was "the product of innumerable small modifications and design improvements," (p. 15).

In the spring of 2011, we conducted a nation-wide survey of thousands of firms in the supply chain. To design the survey, our research team performed dozens of detailed interviews, aiming for a broad picture of the industry. Thus, the plants varied by size, geographic location, and industry. We spoke with engineers, production workers, plant managers, sales managers, and human resources managers, and visited large and small firms, both in the Midwest, the traditional center of the auto industry, and the Southeast, an up and coming center of U.S. auto manufacturing. Industries also varied, including metal-working, assembly, chemicals, rubber, and electronics. Plant visits were

\footnotetext{
${ }^{1}$ From 1980 to 2004, average horsepower for new passenger cars and light-duty trucks increased by $80 \%$ and $99 \%$, respectively. Knittel (2012) estimates that fuel economy could have increased by $60 \%$ during this period had performance been held constant.

${ }^{2}$ Data for 2011 comes from the survey described below; for 1989 data, see Helper (1994) (Technovation). In the earlier period, it was much more common for suppliers to produce parts designed entirely by their customers, the automakers.
} 
indispensable in providing a sense of the type of innovative activities that engineers and others were engaged in, as well as of the language for inquiring about such activity.

The size and strategies of supply chain companies varied tremendously. However, a majority is small- to medium-sized, often family-owned firms. (Data from our survey suggests that firms with fewer than 500 employees account for about one-third of employment in the auto supply chain.) We also observed barriers to patenting for manufacturing firms developing process rather than product innovations. This encouraged us to expand our definition and measurement of innovation to capture a more complete picture of innovative activity taking place in manufacturing firms. We thus hope to contribute to a more recent literature, which focuses on innovative, patentintensive industries such as information and communications technology (i.e., computers, software, telecommunications) or biotechnology and pharmaceuticals, with additional measures of innovation. Interviews also revealed the importance of customers for the innovative efforts of supplier firms. Certain Japanese customers were preferred because they shared expertise and helped suppliers improve, while other, American, customers were viewed as having unreasonable demands for regular, incremental price reductions and did not offer technical or organizational support.

The organization of this chapter is as follows. We first present an overview of our survey and respondent firms. Next, we describe the types of innovative activities performed by engineers and others inside those firms. This is followed by a discussion of the survey data about the workers engaged in this activity, and engineering tasks we measured. Finally, a brief description of customer effects concludes.

\section{Overview of Survey and Respondent Firms}

In order to survey the auto supply chain, we first had to identify firms in the supply chain, which extends several levels from automakers such as Toyota, GM, and Ford. Thus one contribution of this study is to flesh out in a comprehensive fashion the reach of automotive manufacturing in the US. We find an industry dominated by a few enormous firms, supported by thousands of small- and medium-sized enterprises (SMEs); our median respondent had about 100 employees. Another contribution of our survey is therefore a detailed view inside small manufacturing firms, for which very little public data exist. In this section, we describe the process we used to identify firms in the auto supply chain, and then provide a broad overview of those firms.

\section{A. Identifying auto supply chain firms}

A problem that has plagued research on the auto supply chain is that publicly available data do not provide a good picture of which establishments are currently in the auto supply chain. Many firms that supply the auto industry are not classified as auto parts manufacturers (3363, in the North American Industry Classification System, or NAICS), sometimes because they supply other industries and so do not self-identify as auto suppliers. At the same time, many firms than are in NAICS 3363 no longer supply the auto industry, because managers of establishments bear the main responsibility for 
classifying themselves into NAICS codes, and typically do not update these codes very often, even when their markets shift. Thus, in order to survey the automotive supply chain, we first had to determine which firms might be auto suppliers.

We assembled a list of candidate firms and establishments from 11 sources including ELM International, the Analyst Resource Center (ARC), the Michigan Manufacturing Technology Center (MMTC), the Original Equipment Suppliers Association (OESA), the Precision Metalforming Association (PMA), the Industrial Fasteners Institute (IFI), Ohio’s Manufacturing Advocacy and Growth Network (MAGNET), the Automotive News Top 150 Suppliers list, Polymer Ohio, and the Michigan Automotive Research and Development Facilities Directory.

This last directory was particularly useful in identifying firms that specialize in automotive research and development $(R \& D)$ because establishments performing $R \& D$ are classified in NAICS 54171, which at the most detailed category includes "R\&D in the physical, engineering, and life sciences." Thus, it would be very difficult to extract from such a large class of firms those whose output is used primarily by the auto industry. A conservative count of establishments from this directory yields 25,000 employees in Michigan alone. A strictly NAICS-based analysis of the auto supply chain would fail to capture these highly skilled workers, and underestimate the employment, wages, and skill level of automotive production.

From the National Establishment Time Series (NETS) database, we selected firms that were in the auto supply chain using NAICS codes associated with the auto industry (C.A.R. 2010). In addition to 3363, these include functional specialties involved in auto manufacturing, such as metal stamping, plastics manufacturing, and equipment producers, or those performing automotive-related R\&D.

Both manual and automated procedures were used to eliminate duplicate listings. Each of the firms was phoned and asked if they currently supply the auto industry. When called, over half of the establishments listed as NAICS 3363 said that they no longer supplied the auto industry; another one-third were out of business. Table 1 summarizes the outcome of this process. About 20\% of our original list, or 3800 firms, were likely automotive suppliers and only $37 \%$ of the sample was in NAICS 3363 ("Motor vehicle parts manufacturing”).

Three surveys were sent to each firm by e-mail, web link, and mail, each one requiring different expertise: sales, plant management, and personnel. Unfortunately, while the quality of responses received is likely to be high, because respondents were likely to be knowledgeable about their particular area, the share of firms returning all three surveys was relatively low. Out of 1411 responses (a response rate of 37\%), only 98 returned all three surveys. Consequently, in our descriptive statistics, the number of respondents varies.

\section{B. Description of auto supply chain}


The geographical distribution of respondent firms and likely auto suppliers (candidate firms on our list that did not respond to the survey) are similar. Map 1 shows the locations of all plants in our sampling frame in green and respondent plants in red. The greatest concentration of auto supply chain firms is in Michigan, Ohio and Indiana; similarly, nearly two-thirds of our respondents are from this tri-state region.

While the survey was distributed to all firms identified as likely automotive suppliers, these firms fall into "tiers", with "tier-1" firms supplying automakers directly and tier-2 firms supplying tier-1 suppliers, and so on. Some mega-suppliers, such as Visteon, Delphi, Magna, Lear, and Johnson Controls, have many billions of dollars in annual sales, almost all of which come from direct dealings with automakers. Tier-1 suppliers comprise just under $25 \%$ of our sample. Lower tier firms tend to be smaller and more numerous. Figure 1 shows the distribution of respondents by number of employees. A majority of firms had less than 50 employees, and another $40 \%$ of respondents had fewer than 500 . We estimate that about 30 percent of the automotive supply chain employment is at firms with fewer than 500 employees. About $40 \%$ of respondents were single-plant firms, and only $7.8 \%$ of respondents are unionized.

The average age of respondent firms was 32 years, with almost $60 \%$ of firms more than 25 years old. Figure 2 shows the age distribution of the 202 firms that gave their founding year. This suggests that while firms may not be entering the automotive business in large numbers, incumbent firms are robust to the ups and downs of the auto industry. Some of the strategies used by firms to stay afloat resulted in little investment in human or physical capital; one-fourth of them had no engineers at all. Several firms we visited had very little debt, owning their land and equipment outright, which allowed them to slow down operations during the recession through employee furloughs until business picked up again. One firm took the opportunity to purchase used equipment inexpensively from plants that were downsizing or closing.

While we surveyed only firms operating in the US, a number of firms are foreign-owned. In particular, many foreign automakers operate manufacturing plants in the US and source components from American firms as well as foreign suppliers operating in the US. Table 2 shows the top three countries represented in the data. Most, 84\%, are American, $10.5 \%$ are Japanese, and $5.5 \%$ are German. The survey asks only about the component that accounts for the largest share of automotive sales for a supplier; Table 2 shows the country of origin of suppliers' main automotive customer.

\section{Types of Engineering Activity}

What do engineers do? One way of categorizing their activities is in terms of job function within a firm, such as R\&D, product design, process engineering. In a large firm, these might be departments, but in smaller firms, which we targeted for our interviews because most of the firms in our sampling frame are privately owned SMEs, the picture was quite different. We found that a company's only engineer might engage in one or more of these categories of activity in a single day. Some firms were so small that individuals performing these activities identified themselves as manager or owner. Indeed, some 
firms did not view their innovative activity as "R\&D" or even "innovation". This diversity of activities and fluidness of responsibilities within small firms makes measurement problematic.

Measuring activity by job function is a challenge that draws upon an existing literature, and that we hope our survey can contribute to. For example, in measuring R\&D, the literature has measured spending and patents, in large part because these data are publicly available. Cohen and Klepper (1996) review the literature on R\&D spending, which focuses on large publicly traded firms, and Cohen (2010) reviews the empirical literature measuring innovation, including patenting. We inquired about patenting at smaller manufacturing firms. Even though patenting is an important measure of innovative activity or output, prior studies suggest that patents reflect an appropriability strategy, i.e., more patents do not necessarily mean more invention, particularly when comparing across industries (Cohen 2010, Boldrin et al 2011). Our interviews and survey data were consistent with this notion of variable effectiveness of patents: certain types of firms engaged in patenting more than others, but over all, only $3 \%$ of our respondents applied for patents.

For product design, the literature has looked at new product introductions as a measure. This literature has the benefit of extending the large-firm analyses described above by including and even targeting smaller firms. Acs and Audretsch $(1988,1990)$ use product announcements to measure innovation by smaller firms, and Pavitt et al (1987) analyze British data on "significant" new products or processes, many of which are produced by small firms. Process engineering activity has tended not to be the focus of measurement, but a similar study by Leiponen (2005) examines manufacturing firms in Finland (many of which are SMEs) and finds that more-skilled workers are more innovative. In our study, cost reductions are one measure of process engineers' efforts, particularly in a period of rising material costs.

Below, we discuss these categories of engineering activity, describing some context from our interviews and results from our respondents.

\section{A. New Products}

Measuring new product introductions can be an interesting indication of dynamism and change, even for a set of firms that sells products specified by their customer, because turning over products frequently requires flexibility and nimbleness. We asked, "What percent of your sales come from products which you did not make 4 years ago?"

At one factory we visited, an engineer had created a machine out of parts from two disused machines. The new machine was used to produce an item that had been produced by a Chinese competitor but at higher quality and faster delivery than the version overseas.

Another low-tech solution to a customer's problem was found at a chemical company. While this rubber industry firm had several patents for rubber additives and had recently 
begun hiring chemists with doctoral degrees from a local university, one of its more profitable areas was its "cake mix" product line. Managers at the firm had noticed its customers buying the same combinations of chemicals and having to measure and mix them. They had the idea to make easy-to-use, pre-mixed packages, which would make their customers' outcomes more consistent and result in higher profits for the firm.

The introduction of new products designed by clever engineers is clearly a useful form of innovation. This does not mean that slow product turnover implies uninventive engineers. Rather, the frequent change in product line may be a distinct innovation strategy. Figure 4 shows the frequency of our responses. About a third introduced a new product at least every year, if not more.

\section{B. Design}

In a manufacturing supply industry, engineers often take completed designs from their customers and produce them exactly as specified. In such cases, no additional design work is involved. On the other hand, the "cake mix" products described above are designed entirely by supplier firm managers, albeit with considerable input from and observation of their customers. Because "design" is to some extent an innovative activity, we ask, "In the past year, roughly what percent of your plant's sales were from jobs where your firm designed the part or assembly?"

Figure 5 shows the considerable heterogeneity of responses to our question. A third of respondents fit the traditional model of supplier firm, producing only products designed by their customers. But about $15 \%$ produce parts that they design themselves. The rest, a majority of firms, fall somewhere in between these two extremes.

\section{Innovative contribution}

Our broadest innovation question asks, "What percent of your sales come from products where you innovated in some way? By 'innovated', we mean that your business unit designed a product with improved features compared to what the market had seen before, or that you used a novel process to make the product."

This is a somewhat catch-all question, but it is meant to encourage respondents to consider process innovations as well as product innovations when assessing their innovative contribution. One metal stamping firm we visited was continually developing and extending its process capability, constantly creating new "know-how". For example, the owner of the firm worked with engineers to refine processes to accommodate very thin material, including plastics. This enabled the firm to serve an East Coast customer producing electric generators, a customer outside the usual geographical region and customer industry.

Even with our liberal definition of innovation, almost $42 \%$ of respondents report contributing little or no innovation to the products they make. At the other end of the spectrum, about $15 \%$ contributed some innovation to half their products or more. 


\section{Cost reduction}

Manufacturing cost reductions are often associated with economies of scale-as production quantities increase, the average cost goes down as a fixed component of cost is spread over more units. But process improvements can also generate cost reductions, for example through fewer errors or more reliable equipment. We observed efforts in both of these directions on our plant visits.

There were also clever applications of existing processes to reduce the cost of a component. A process engineer could help its firm win new business by extending and applying its process capabilities. For instance, one metal stamper we visited bought a large press capable of stamping inch-thick material, which was much thicker than the sheet metal that their current machinery was capable of punching through. This stamper was able to produce a part that had previously been produced by casting, a much more costly and energy-intensive process that involves pouring molten metal into a mold.

At another firm, process engineers added welding capability to the firm's production technologies. This allowed the firm to make a part using two stamped pieces that were joined together by welding. The welded assembly replaced a more costly cast part that its customer was importing from a low-wage country.

Figure 3 shows responses to our question about cost reduction. About $15 \%$ of firms reduced their costs, with another $40 \%$ maintaining cost levels. These responses are particularly interesting during our survey period because commodity prices were increasing. Thus cost reductions, and even holding costs level, are likely the result of successful engineering efforts. Note that at some firms, customers demand a schedule of price reductions. These price reductions might be accompanied by incremental process improvements, but if not, they could be met by a reduction in the firm's profits. Our question allows us to distinguish price reductions from cost reductions.

While these types of innovations produced by engineers at manufacturing firms seem minor, incremental innovations that reduce cost and create value for customers constitute a phenomenon of economic importance when aggregated across the thousands of firms that make up the auto industry. However, because each incremental innovation might seem unimportant, even to the engineer, measuring and valuing this activity can be difficult. Small firms rarely measure R\&D spending, and their engineers tend to perform a variety of tasks, including innovation-related tasks. Many of the firms we interviewed eschewed the very term "innovation" as too sophisticated to describe their on-going efforts to reduce cost and remain competitive. The experiments and development of new processes are carried out by the same engineers and technicians that maintain existing production lines and develop its traditional tooling, which helps explain why many firms lack careful formal accounting of $R \& D$ as a separate activity. We hope our additional measures can help overcome some of these issues for SMEs in manufacturing. 


\section{Engineering Interactivity}

In the previous section, we categorized engineering activities in terms of function within a firm. In this section, we consider a different type of categorization: interactivity, with customers and with other functions inside the firm. We have described a work environment for manufacturing engineers of diverse activities, including maintaining existing processes on a daily basis but also developing new processes, refining and extending old processes, and solving customer problems to win new business. Amidst this mix of activities, we also examine how, and how much, engineers interact with others. First, we look at interaction with customers, using questions in our survey about certain investments and communications patterns. We then look at how much overlap there is between engineering tasks and the tasks of other types of workers, including skilled trades, production workers, and managers.

\section{A. Interaction with customers}

The literature has long considered demand for a product to be relevant to innovation; Schmookler (1966) argued that innovation would be greater for goods that had a large market. In the context of a supply chain, demand considerations focus attention on buyersupplier relationships, especially in the auto industry, with its oligopsonistic buyers. Outside of the corporate venture capital literature (e.g., Benson and Ziedonis 2009), relatively little research has been done on innovation by firms that sell to a few large customers.

Our interviews suggest wide variation among customers, including a distinct preference for Japanese customers, who were valued for their fairness and for their willingness to invest in suppliers. One steel maker credited its Japanese customer for helping it improve so much that, rather than go out of business, it was able to compete even in a downturn. The literature on Japanese sourcing practices show Japanese automakers providing training and management assistance to suppliers (MacDuffie and Helper 1997), as well as their efficient organization of operations (Womack, Roos and Jones 1990). ${ }^{3}$ German customers were also viewed as fair by our interviewees, but less involved in the improvement and investment of their suppliers. ${ }^{4}$

To see how customer collaboration and communication benefited suppliers, we asked firms about "useful information that personnel at your plant have received on new products your firm might introduce and new processes your firm might adopt." Figure 8 shows respondents obtaining both types of information, but slightly more product

\footnotetext{
${ }^{3}$ Some of this may be a result of practices in Japan where regular employees receive extensive on-the-job training, and employment norms have made it difficult for regular workers to change companies midcareer. This reduced labor mobility affects appropriability among Japanese firms, as company-trained employees are unlikely to take their skills with them to a competitor, or inventive employees take inventions to another firm.

${ }^{4}$ As with Japanese customers, German customers might be affected by practices in their home country. There, automakers use small supplier firms, aided by nationally subsidized training systems that produce highly skilled shop-floor employees who cooperate in R\&D activities (Ezell and Atkinson 2011).
} 
information than process information. Indeed only $10-20 \%$ of firms were getting no ideas from their customers.

We also asked about several specific engineering methods that we thought might be broadly representative of two different customer-service strategies: finite element analysis and value analysis/ value engineering.

Finite element analysis (FEA) is the assessment of a component's suitability for its operating environment. Engineers use costly specialized software that incorporates scientific knowledge to evaluate an auto part's strength and durability in a given situation. For example, an engineer performing FEA on an engine component would use his software tools to judge whether the part was capable of withstanding the pressure, heat, impact, and other known environmental stresses, and whether the part could perform at the desired level of reliability and durability. The use of FEA tools requires that an engineer have specific training, as well as general scientific knowledge. However, this analysis can be performed as an independent task with a minimum of interaction with the customer.

By contrast, value analysis/ value engineering (VAVE) involves extensive interaction between customer and supplier on a variety of design and manufacturing decisions. The purpose of VAVE is for suppliers to improve "value" to customers, which is defined as performance divided by cost. Engineers therefore make an effort to learn about their customer's needs broadly, and work with their customer to design a product or process. The chemical company that produced "cake-mix" products is one example of this type of customer-oriented approach, but efforts vary depending on the type of supplier firm and the extent of customer interaction. By contrast, a more conventional, non-VAVE approach to supplying components would take a customer's design as complete. The supplier would produce the part without modification or input, and many of our survey respondents take this more traditional approach.

Comparing the two, FEA involves an investment in equipment and engineers with specialized knowledge and skills, whereas VAVE requires engineers to spend time interacting with customers and to think broadly about customer problems and solutions. Thus, FEA and VAVE represent different strategies for investment and skills. However, they are not really polar opposites; some firms do both. Table 3 shows the breakdown of the 474 firms that responded to our questions about the use of FEA and VAVE, and we see that a majority of firms that provide VAVE services also provide FEA. Despite the proven effectiveness of both techniques, they remain rare in the U.S. industry; only $1 / 3$ of respondents practiced VAVE, and only $1 / 4$ had implemented FEA.

VAVE is only one measure of customer interaction. While a majority of firms, $60 \%$ of respondents, reported using neither FEA nor VAVE, some of these firms collaborate with customers outside of a VAVE framework. Table 4 shows responses to more general questions about customer interactions. We ask whether the supplier conducts regular or occasional visits with their customers, and more specifically, with their customer's engineers. The responses to both questions are almost identical; a majority of firms visit 
at least occasionally, with 30\% visiting regularly. The engineering intensiveness of a firm's strategy is also reflected in employment data. Figure 7 shows the highly skewed distribution of engineering employment at our respondent firms. Over 20\% of the 647 firms that listed employment numbers had no engineers at all, and nearly one-third had just one to three engineers on staff. The picture that emerges is of a spectrum of firms ranging from low engineering-intensity and low customer engagement to high engineering-intensity and customer collaboration. Firms that perform VAVE had an average of 7.24 engineers on staff, compared with 4.76 for firms that do not perform VAVE. Similarly, firms that make regular visits with customer engineers had an average of 6.21 engineers compared with 4.06 for firms that do not make regular visits.

\section{B. Interaction with other workers}

Within a firm, engineers may interact with other workers, especially skilled workers and unskilled production workers. We measure engineers' interaction with production work by asking whether non-engineers perform the following six engineering tasks: set up machines, modify programs on computerized equipment, diagnose equipment problems inspect work in progress, use quality assurance data to recommend improvements, meet with customer personnel and use a computer. Our idea is that the more "task overlap" there is, the more interaction non-engineering workers have with engineers.

Because one feature of Japanese manufacturing organization is close interaction between engineers and production workers, we compare task overlap at US firms and Japanese firms. Table 5 shows much greater task overlap between skilled workers and engineers than unskilled workers and engineers, not surprisingly. There is also a slightly higher rate of overlap for both types of workers within Japanese-owned firms in the US. Out of six tasks we asked about, skilled workers and engineers overlapped on 4.8 of them in Japanese-owned firms, and 4.5 in US-owned firms.

Table 6 shows regression results for how overlapping of duties, or interaction between engineers and production workers, is associated with value-added per employee. Overlap with production workers is positive and significant. However, as the second column shows, this coefficient is no longer significant once we control for size, as represented by

sales. This result is somewhat surprising, because one might think that a larger size would allow more division of labor (rather than task overlap). Engineering intensity (number of engineers/total employment) is not significant, nor is the country of ownership (with US omitted).

\section{Discussion \& Conclusion}

An economically important industry that has produced significant gains in product performance, the auto industry increasingly relies on suppliers not only for manufacturing but also for innovation. Engineers at supplier firms contribute innumerable incremental gains, that they themselves deem unworthy of the term "innovation". Nevertheless, skills 
and customer collaboration generates a steady improvement in price, performance, or both.

We hope our study contributes to an extensive and varied literature on engineering and innovation by providing insight and detail about how engineers generate innovation, especially in a manufacturing context where patenting is uncommon. Our survey provides a variety of ways to inquire about and measure innovative output, in addition to patenting or R\&D spending. A correlation matrix of these measures shows how uncorrelated these additional measures are from the standard variables standard in the literature (Table 7). This is partly because of inadequate measurement, with engineers wearing many hats and not getting accounted for as R\&D investment, but also because patenting is not suitable for much of the innovative output at these firms.

Finally, our interviews serve to illustrate how diverse engineering activity can be. Engineers produce new chemical compounds but also "cake-mixes"; they build complex dies and stamping processes but also cobble together two old machines. The application of formal training and on-the-job know-how seems to characterize firms that survive wide swings in demand and move technology forward. 


\section{$\underline{\text { References }}$}

Acs, Zoltan J. and David B. Audretsch, "Innovation in Large and Small Firms: An Empirical Analysis," AER 78, 4 (1988): 678-690.

----- , Innovation and Small Firms (Cambridge: MIT Press, 1990).

Benson, David and , "Corporate Venture Capital and the Returns to Acquiring Portfolio Companies,” Journal of Financial Economics 98, 3 (2010): 478-499.

C.A.R., Contribution of the Automotive Industry to the Economies of All Fifty States and the United States (Center for Automotive Research, Ann Arbor, 2010).

Clark, Kim B., Bruce W. Chew, and Takahiro Fujimoto, "Product Development in the World Auto Industry," Brookings Papers on Economic Activity 3 (1987): 729-781.

Cohen, Wesley M., "Empirical Studies of Innovative Activity and Performance,” in Handbook of the Economics of Innovation, Volume 1 (Handbooks in Economics), edited by Bronwyn Hall and Nathan Rosenberg. Elsevier, 2010.

----- and Stephen Klepper, “A reprise of size and R\&D,” Economic Journal 106 (1996): 925-951.

Ezell, Stephen J. and Robert D. Atkinson, International Benchmarking of Countries’ Policies and Programs Supporting SME Manufacturers (Information Technology and Innovation Foundation, 2011).

Levin, R. C., A. K. Klevorick, R. R. Nelson, and S. G. Winter, "Appropriating the Returns from Industrial Research and Development," Brookings Papers on Economic Activity 3 (1987): 783-820.

Knittel, Christopher R, "Automobiles on Steroids: Product Attribute Trade-Offs and Technological Progress in the Automobile Sector," AER 101 (2012): 3368-3399.

Leiponen, Aija, “Skills and innovation,” International Journal of Industrial Organization, 23 (2005): 303-323.

MacDuffie, John Paul and Susan Helper, "Creating Lean Suppliers: Diffusing Lean Production Through the Supply Chain," California Management Review 39, 4 (1997): 118-151.

Pavitt, K., M. Robson, and J. Townsend, "The size distribution of innovating firms in the UK: 1945-1983," Journal of Industrial Economics 35 (1987): 297-316.

Rosenberg, Nathan, "Technological Change in the Machine Tool Industry, 1840-1910," Journal of Economic History. 23, 4 (1963): 414-443. 
---------, and Edward Steinmueller, "Engineering Knowledge," SIEPR Discussion Paper no. 11-022 (2010), Stanford University.

Schmookler, J., Invention and Economic Growth. (Cambridge: Harvard University Press, 1966).

International Trade Administration, Office of Transportation and Machinery, On the Road: U.S. Automotive Parts Industry Annual Assessment (United States Department of Commerce, 2011).

http://www.trade.gov/mas/manufacturing/oaai/build/groups/public/@tg_oaai/documents/ webcontent/tg_oaai_003748.pdf

Womack, James P., Daniel Roos and Daniel T Jones, The Machine that Changed the World: The Story of Lean Production (New York: Scribner, 1990). 
$\underline{\text { Table 1: Construction of Survey Sample }}$

\begin{tabular}{|c|c|c|}
\hline NAICS & Candidate Firms by NAICS Code & Percent \\
\hline 3363 & Motor vehicle parts manufacturing & $37.1 \%$ \\
\hline 333514 & Special die and tool, die set, jig, and fixture manufacturing & $14.3 \%$ \\
\hline 326199 & All other plastics product manufacturing & $12.8 \%$ \\
\hline 332116 & Metal stamping & $1.4 \%$ \\
\hline 332710 & Machine shops & $1.1 \%$ \\
\hline 326220 & Rubber and plastics hose and belting manufacturing & $0.9 \%$ \\
\hline \multirow[t]{3}{*}{336211} & Motor vehicle body manufacturing & $0.2 \%$ \\
\hline & Other industries & $\underline{32.3 \%}$ \\
\hline & Total & $100.0 \%$ \\
\hline$\underline{\mathbf{N}}$ & $\underline{\text { Reason for Elimination from Sample }}$ & \\
\hline 3646 & Out of business & $19.2 \%$ \\
\hline 11,363 & Not in auto industry & $59.9 \%$ \\
\hline 130 & Duplicates & $\underline{0.7 \%}$ \\
\hline 3828 & Total Remaining & $20.2 \%$ \\
\hline
\end{tabular}

$\underline{\text { Table 2: Country of origin, customers and suppliers }}$

\begin{tabular}{lccccc}
\hline \hline & $\begin{array}{c}\text { US } \\
\text { customer }\end{array}$ & $\begin{array}{c}\text { Japanese } \\
\text { customer }\end{array}$ & $\begin{array}{c}\text { German } \\
\text { customer }\end{array}$ & Total & \% of total \\
\hline US supplier & 307 & 129 & 27 & 463 & $84 \%$ \\
Japanese supplier & 13 & 41 & 4 & 58 & $10.5 \%$ \\
German supplier & 14 & 7 & 9 & 30 & $5.5 \%$ \\
\hline \hline
\end{tabular}

Table 3: Use of FEA and VAVE

\begin{tabular}{lcc}
\hline \hline & VAVE & No VAVE \\
\hline FEA & $17 \%$ & $8 \%$ \\
No FEA & $15 \%$ & $59 \%$ \\
\hline \hline
\end{tabular}


$\underline{\text { Table 4: Visits with customers }}$

\begin{tabular}{lcc}
\hline \hline & Customer & $\begin{array}{c}\text { Customer's } \\
\text { engineers }\end{array}$ \\
\hline None & $47 \%$ & $41 \%$ \\
Occasional & $22 \%$ & $28 \%$ \\
Regular & $31 \%$ & $31 \%$ \\
\hline \hline
\end{tabular}

Table 5: Number of Tasks Overlapping with Engineers by US and Japan

\begin{tabular}{|c|c|c|c|}
\hline & & US & Japan \\
\hline \multirow[t]{2}{*}{$\begin{array}{l}\text { Unskilled/ } \\
\text { Semi-skilled }\end{array}$} & $\begin{array}{l}\text { Average } \\
\text { (std. dev.) }\end{array}$ & $\begin{array}{c}2.25 \\
(1.80)\end{array}$ & $\begin{array}{c}2.74 \\
(1.39)\end{array}$ \\
\hline & Range & $0-6$ & $0-6$ \\
\hline \multirow[t]{2}{*}{ Skilled } & $\begin{array}{l}\text { Average } \\
\text { (std. dev.) }\end{array}$ & $\begin{array}{c}4.51 \\
(1.31)\end{array}$ & $\begin{array}{c}4.81 \\
(1.28)\end{array}$ \\
\hline & Range & $0-6$ & $0-6$ \\
\hline $\mathrm{N}$ & & 404 & 31 \\
\hline
\end{tabular}

Table 6: Value added per employee and engineering intensity, country and skill overlap (OLS)

\begin{tabular}{lcc}
\hline \hline Ln(value-added) & $(1)$ & $(2)$ \\
\hline Engineering intensity & 0.61 & 1.04 \\
& $(1.09)$ & $(1.02)$ \\
\hline Japanese supplier & -0.27 & -0.68 \\
& $(0.48)$ & $(0.46)$ \\
German supplier & 0.59 & -0.41 \\
& $(0.75)$ & $(0.75)$ \\
Other supplier & 0.26 & -0.09 \\
& $(0.31)$ & $(0.31)$ \\
\hline Unskilled overlap & $0.13^{* *}$ & 0.06 \\
& $(0.06)$ & $(0.06)$ \\
Skilled overlap & -0.02 & -0.06 \\
& $(0.08)$ & $(0.08)$ \\
\hline Size (ln sales) & & $0.23^{* * *}$ \\
& & $(0.06)$ \\
\hline R2 & 0.06 & 0.20 \\
$\mathrm{~N}$ & 94 & 94 \\
\hline \hline
\end{tabular}


Table 7: Correlaction matrix: innovation variables

\begin{tabular}{|c|c|c|c|c|c|c|}
\hline & $\begin{array}{l}\text { R\&D } \\
\text { spending }\end{array}$ & $\begin{array}{l}\text { New } \\
\text { products }\end{array}$ & $\begin{array}{l}\text { Innovated } \\
\text { products }\end{array}$ & $\begin{array}{l}\text { Cost } \\
\text { reduction } \\
\text { (1 year) }\end{array}$ & $\begin{array}{l}\text { Cost } \\
\text { reduction } \\
\text { ( } 4 \text { years) }\end{array}$ & Patents \\
\hline $\begin{array}{l}R \& D \\
\text { spending }\end{array}$ & 1 & & & & & \\
\hline New products & 0.09 & 1 & & & & \\
\hline $\begin{array}{l}\text { Innovated } \\
\text { products }\end{array}$ & $0.33 * * *$ & $0.26 * * *$ & 1 & & & \\
\hline $\begin{array}{l}\text { Cost } \\
\text { reduction } \\
\text { (1 year) }\end{array}$ & $0.11^{* *}$ & -0.01 & 0.03 & 1 & & \\
\hline $\begin{array}{l}\text { Cost } \\
\text { reduction } \\
\text { ( } 4 \text { years) }\end{array}$ & 0.05 & 0.00 & -0.00 & $0.64 * * *$ & 1 & \\
\hline Patents & 0.03 & -0.01 & 0.00 & 0.01 & -0.01 & 1 \\
\hline
\end{tabular}

Figure 1: Survey respondents by number of employees

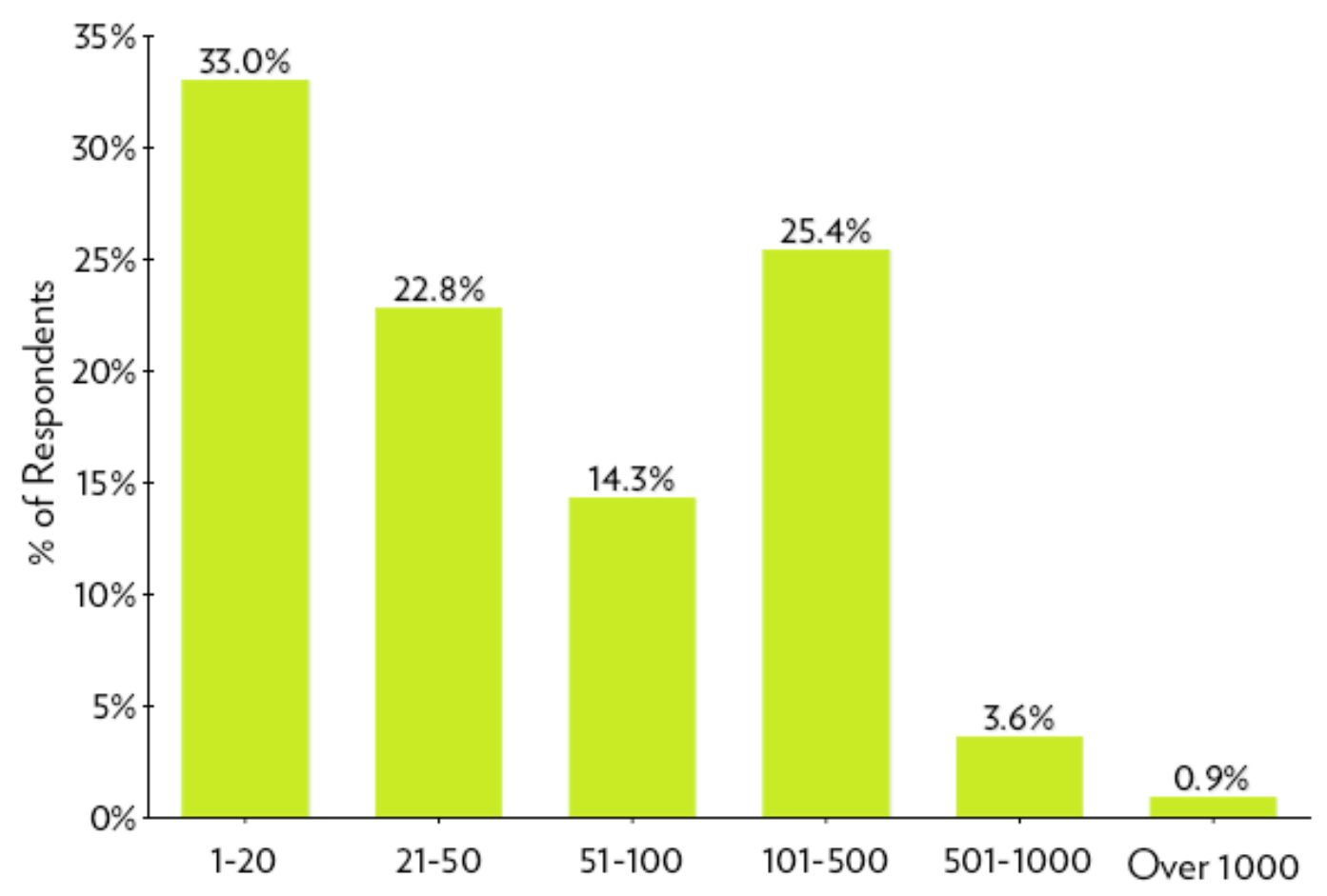


Figure 2: Age distribution of supply chain firms

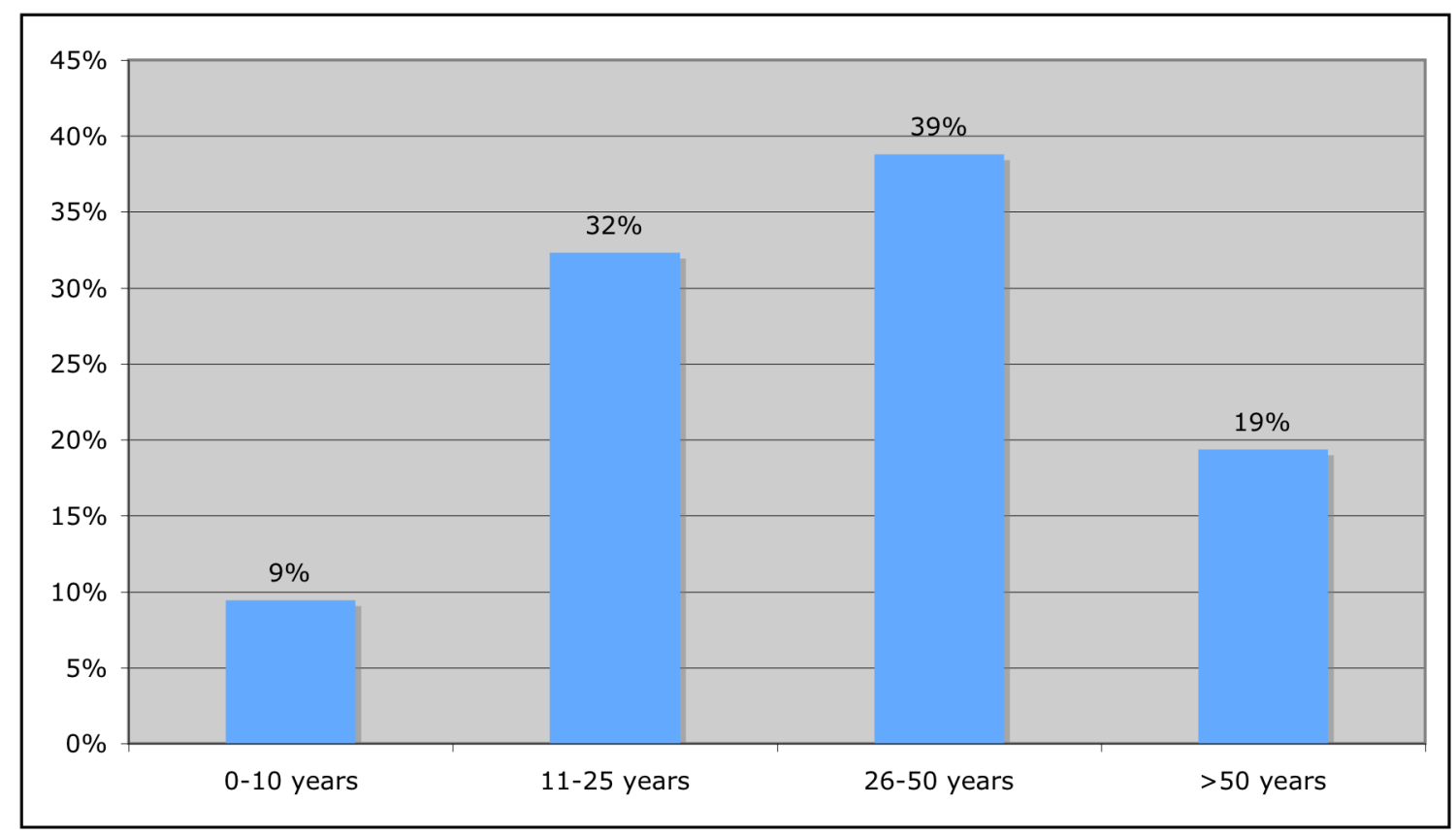

Figure 3: "What has been the average annual percent change in your unit costs?"

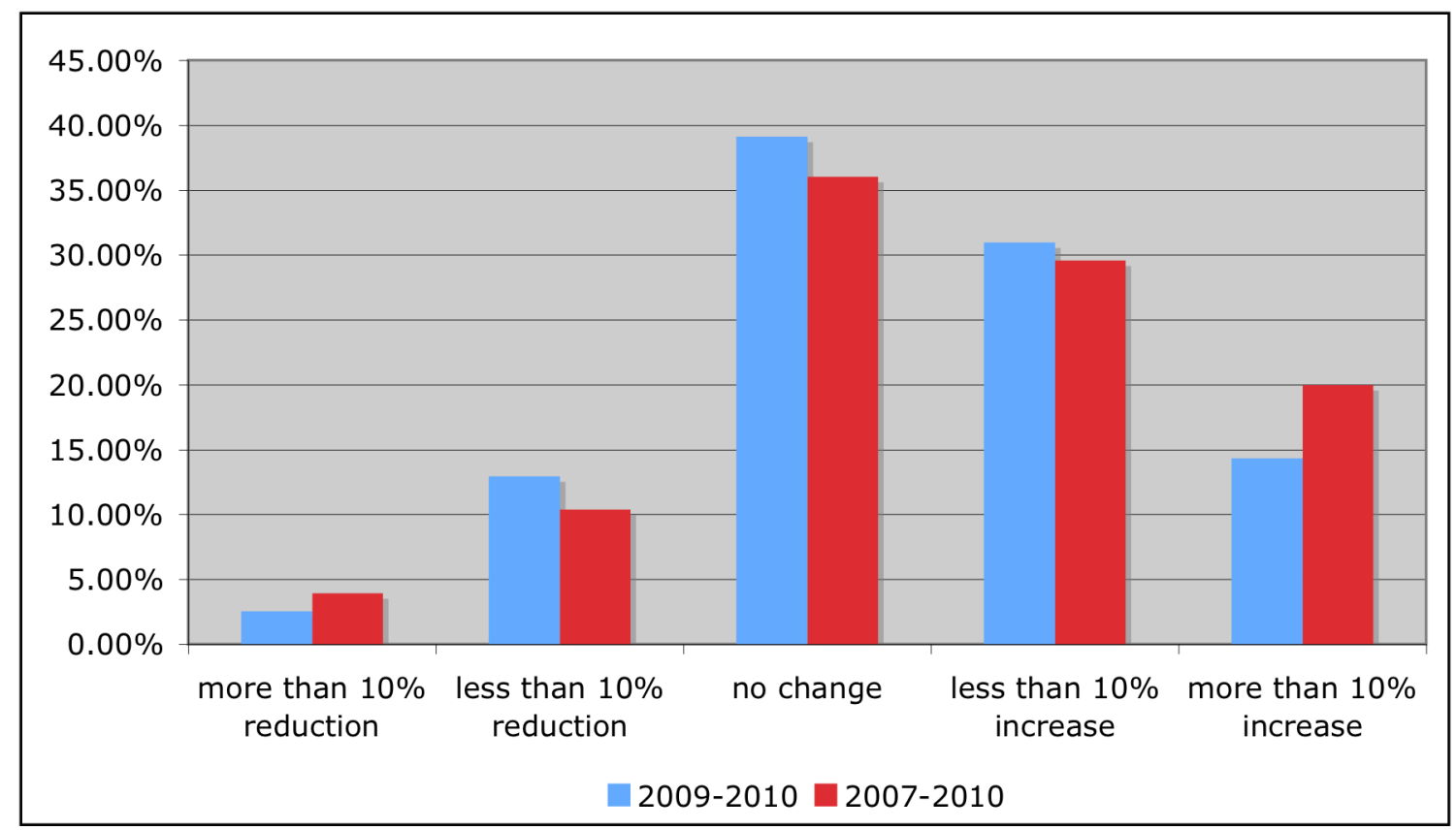


Figure 4: What percent of your sales come from products which you did not make 4 years ago?"

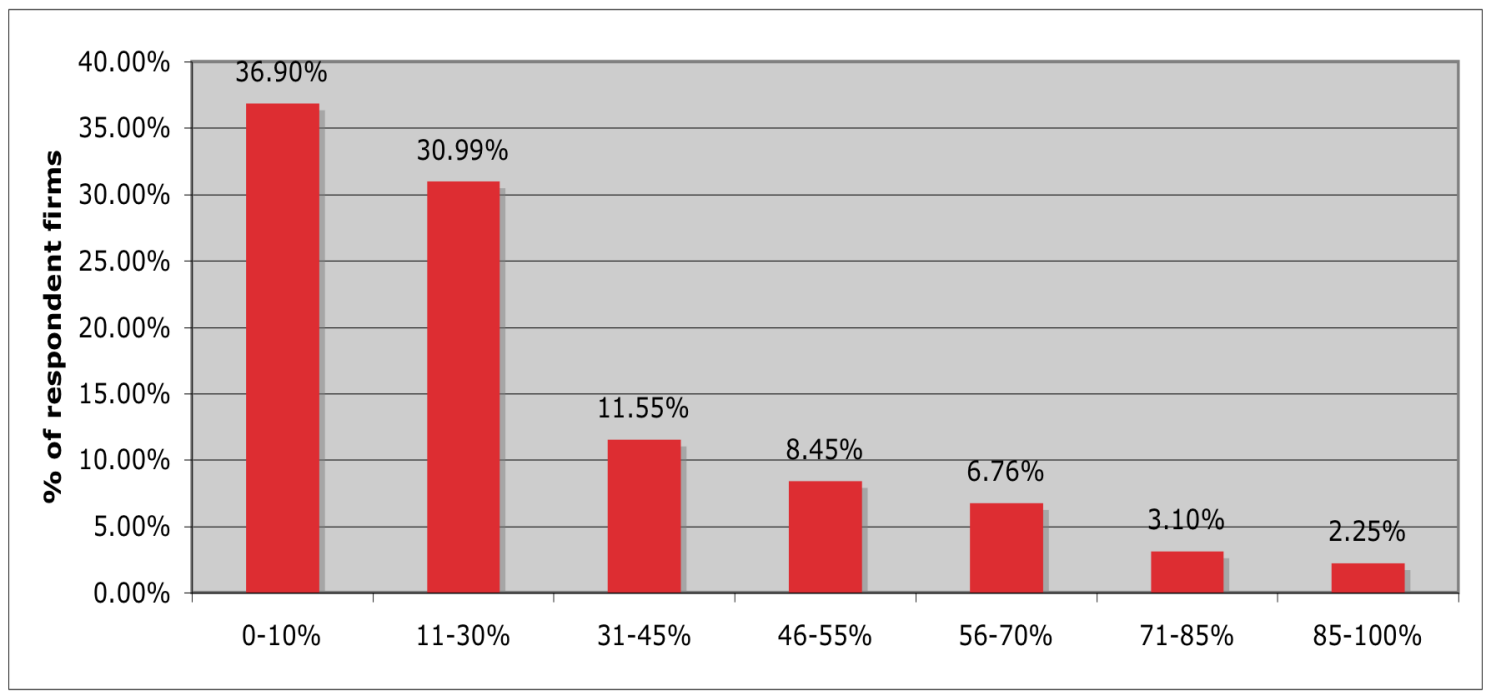

Figure 5: In the past year, roughly what percent of your plant's sales were from jobs where your firm designed the part or assembly?

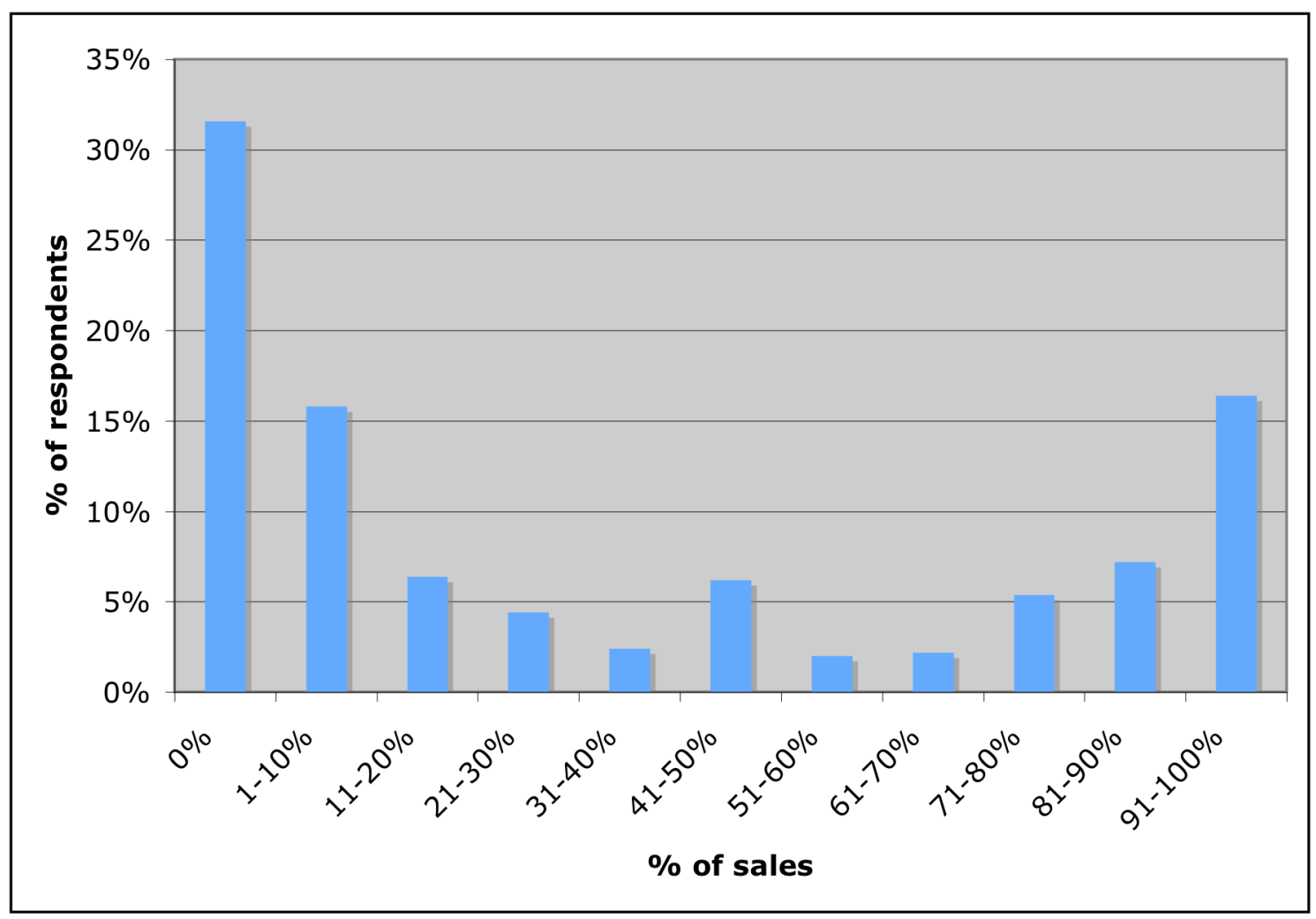


Figure 6: "What percent of your sales come from products where you innovated in some way? By 'innovated', we mean that your business unit designed a product with improved features compared to what the market had seen before, or that you used a novel process to make the product."

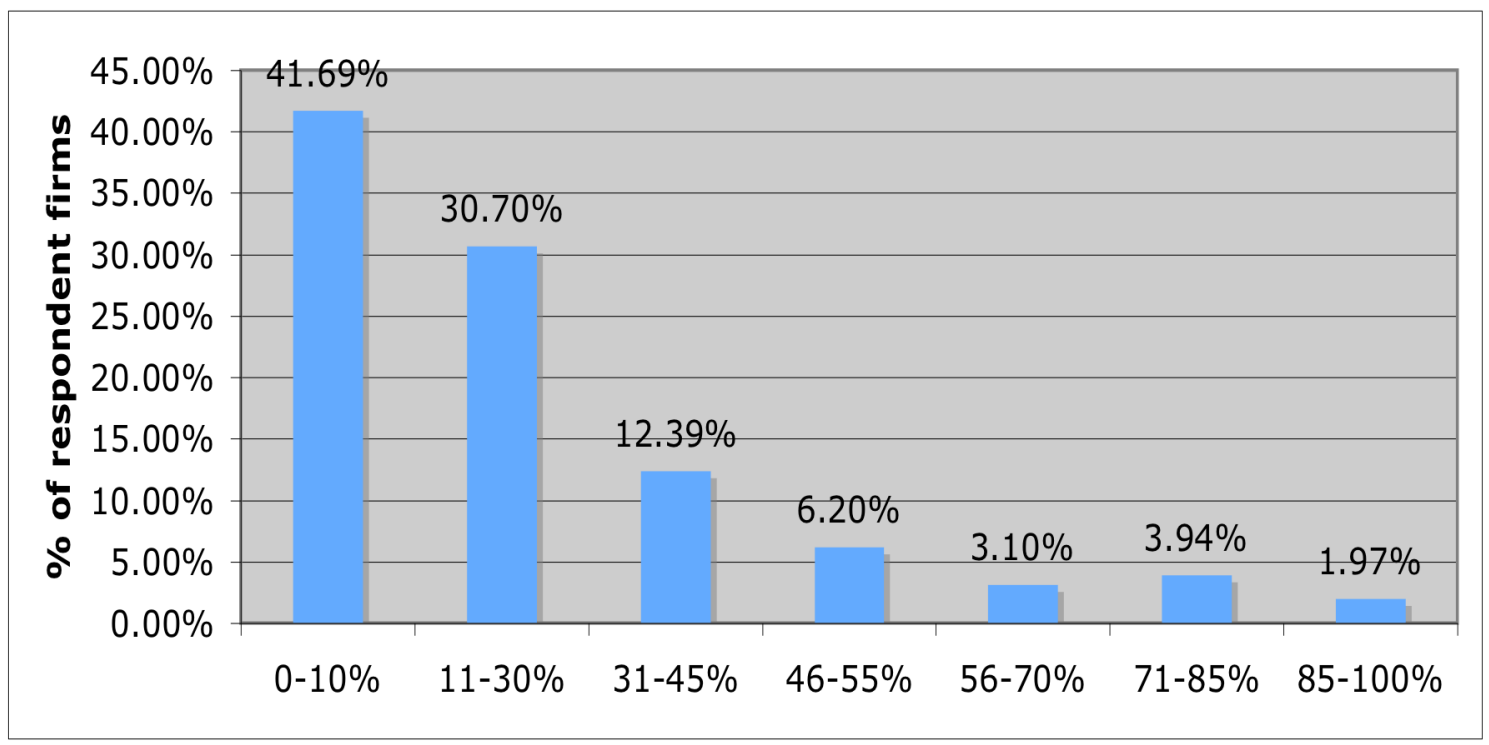

Figure 7: Number of engineers employed by firms (top coded at 100+)

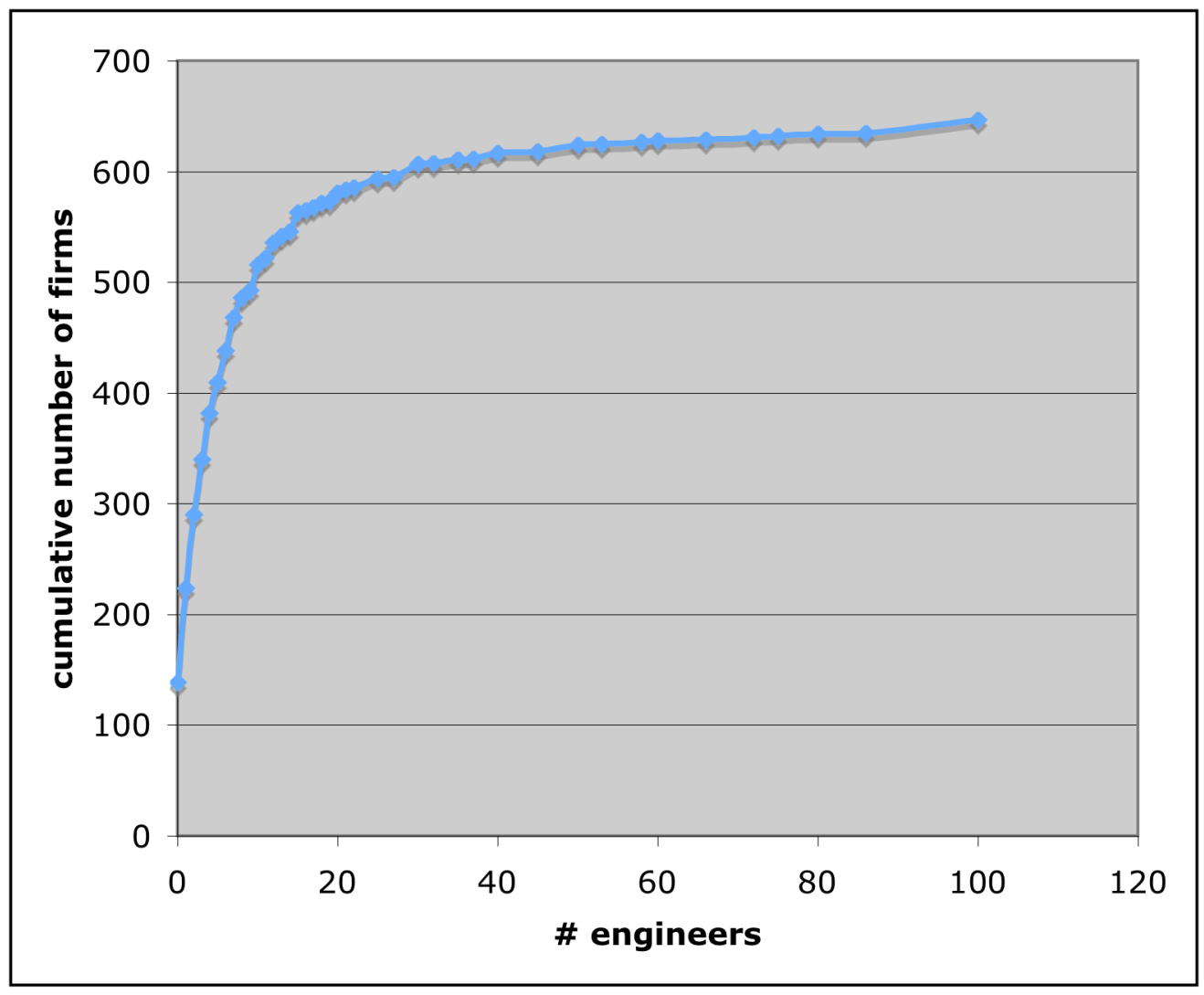


Figure 8: Product and process information from customers

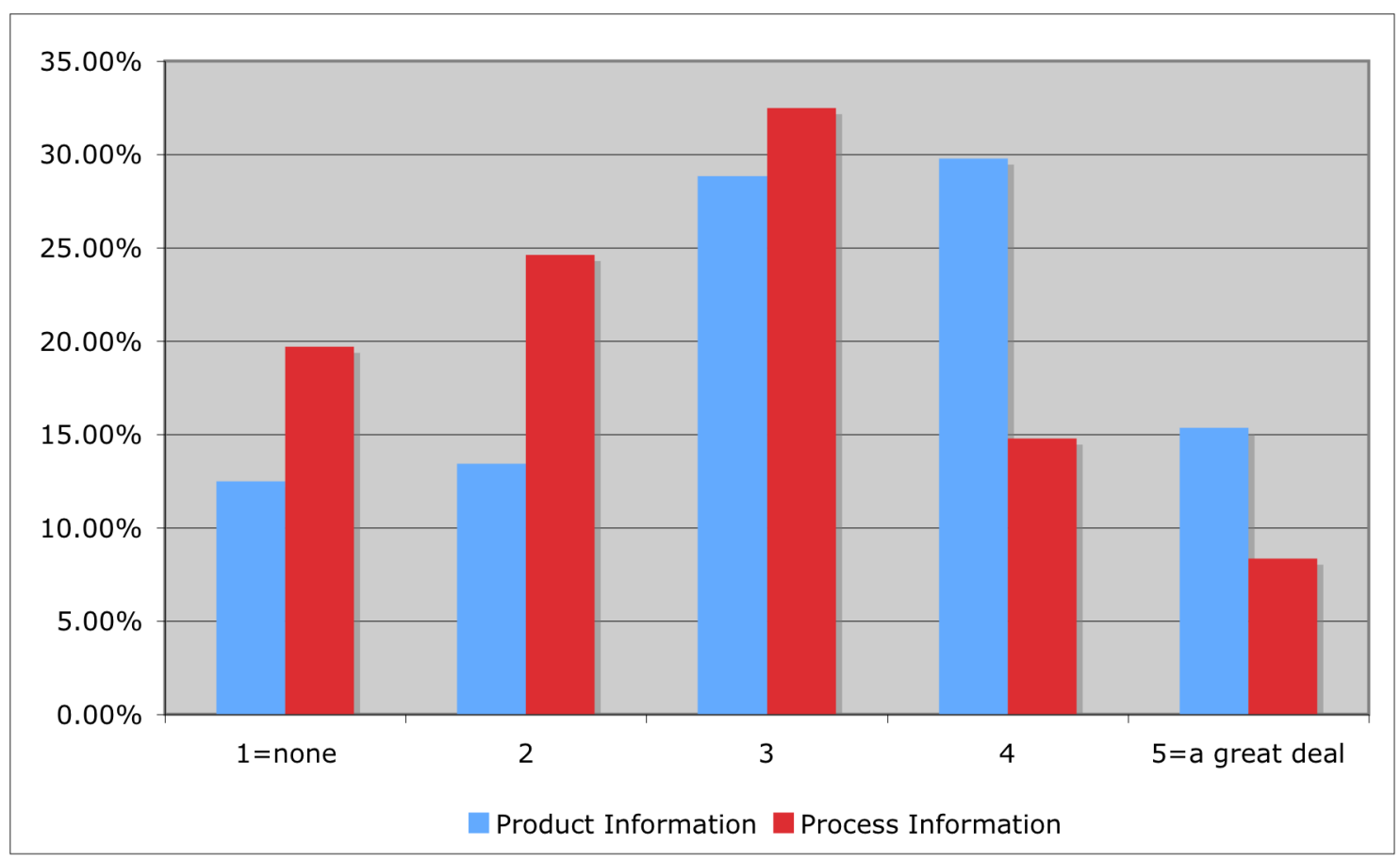

Figure 9: Customers as a source of new information for products and process (scale: $1=$ no new information $-5=$ a lot of new information)

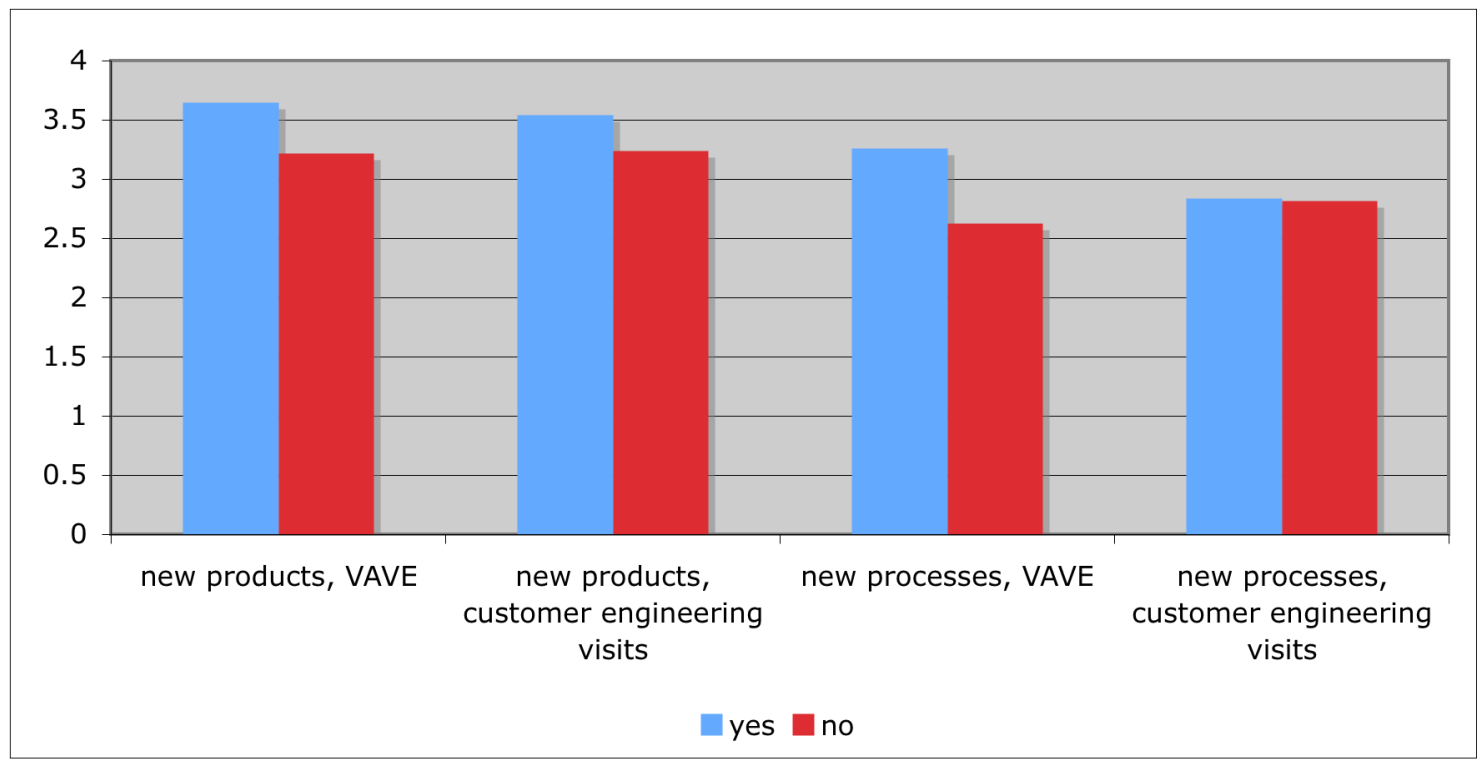


Figure 10: Proportion of firms anticipating difficulty finding workers with indicated skills by job classification

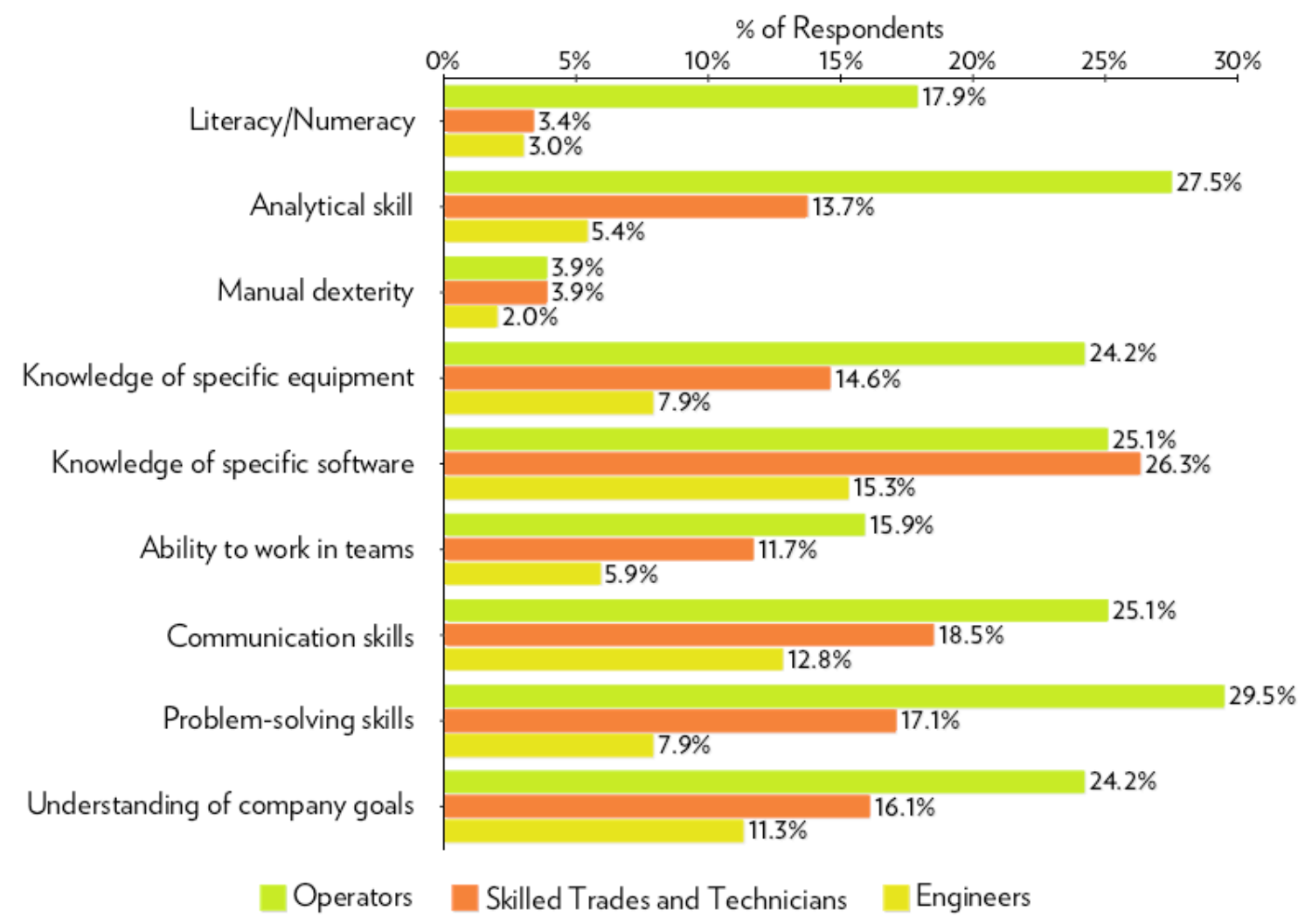

Map 1: Location of Survey Respondents

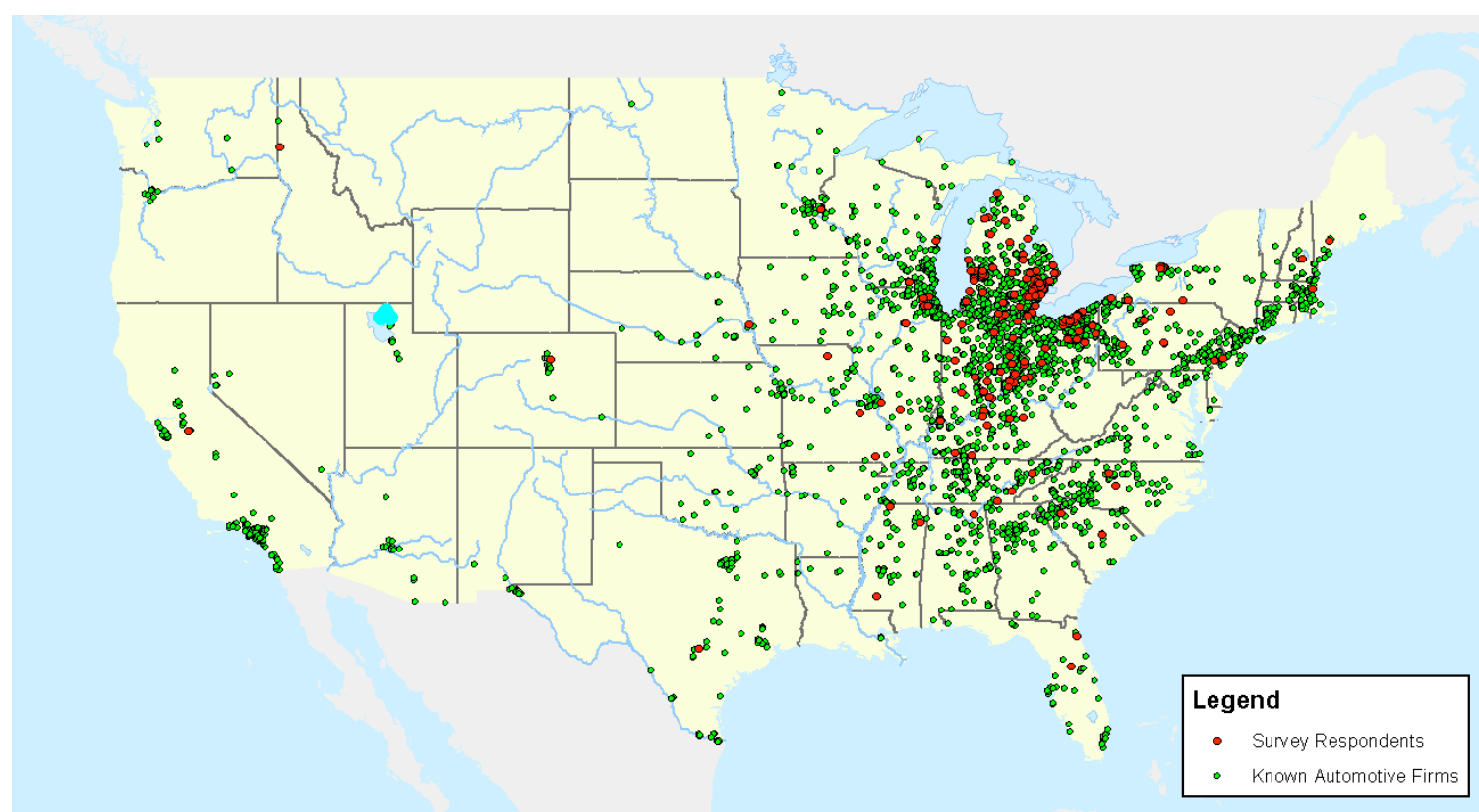

